\title{
ФИЛОЛОГИЯ
}

DOI: 10.17805/ggz.2018.2.8

\section{Об энциклопедических очерках Вл. А. Лукова «Европейская культура в русском тезаурусе»}

В. С. Рабинович, М. Ю. Мухин

Уральский федеральный университет имени первого Президента России Б. Н. Ельцина, г. Екатеринбург

Статья содержит трактовку энииклопедических очерков видного культуролога и литературоведа Вл. А. Лукова (1948-2014) «Европейская культура в русском тезаурусе», вышедших в трех томах в издательстве Московского гуманитарного университета в 2018 г. Показано, что программа исследования, лежащая в основе энциклопедических очерков, затрагивает социокультурные прочессы Европы, систематизированные с точки зрения русского тезауруса.

Ключевые слова: тезаурусный подход; русский тезаурус; европейские социокультурные процессы; европейская культура

\section{On the Encyclopedic Essays \\ "European Culture in the Russian Thesaurus" by Vladimir A. Lukov}

V. S. Rabinovich, M. Yu. Mukhin

Ural Federal University named after the first President of Russia

B. N. Yeltsin, Ekaterinburg

The article contains an interpretation of the encyclopedic essays by the prominent cultural and literary scholar Vladimir A. Lukov (1948-2014), "European Culture in the Russian Thesaurus" published in three volumes in the Publishing House of Moscow University for the Humanities in 2018. It is shown that the research program compiling these encyclopedic essays touches upon social and cultural processes in Europe that are systematized from the viewpoint of the Russian thesaurus.

Keywords: thesaurus approach; Russian thesaurus; European socio-cultural processes; European culture

В энциклопедических очерках Вл. А. Лукова на обширном материале произведений европейских авторов, фактов их биографий, мнениях современников проведен масштабный анализ европейского социокультурного пространства, соотнесенный с тезаурусным подходом (Луков, 2018abc). Про- 
грамма исследования, лежащая в основе энциклопедических очерков, затрагивает социокультурные процессы Европы, систематизированные с точки зрения русского тезауруса - свода знаний, маркированного национальнокультурными особенностями носителей языка.

Значимыми в теоретическом плане представляются идеи субъектнообъектной культурологии и литературоведения. Полагаем, что подобный подход позволяет применить оригинальную исследовательскую оптику к явлениям, детерминирующим социокультурную динамику европейского общества. Важной с точки зрения стабилизации круга вопросов, рассматриваемых в рамках современной культурологии, является идея об автономном описании культурной картины мира, сегментами которой являются научная и художественная картины мира (Луков В., Луков Вл., 2013). Считаем, что применяемый метод способствует седиментации лингвокультурологического опыта.

Филологическая направленность очерков Вл. А. Лукова заключается в фиксации фактов языка европейских авторов, их трактовке и грамотной интерпретации. Эти факты наглядно иллюстрируют поведенческие тактики и социокультурные повседневные практики европейцев, актуализованные в произведениях европейских авторов и подвергшиеся рефлексии на российской почве.

Наряду с безусловной научной ценностью, энциклопедические очерки Вл. А. Лукова представляют собой ценный культурный феномен и в принципе могут рассматриваться как значимое явление современной отечественной культуры. В самом деле, русская культура, в том числе в ее литературных репрезентациях, соприкасается в первую очередь с культурой европейской: и основные направления развития русской культуры (и литературы не в последнюю очередь), и этапы ее развития напрямую соотнесены с соответствующими «европейскими» культурными феноменами. Энциклопедические очерки Вл. А. Лукова как раз и представляют культурную ценность как развернутое описание взаимодействия русской культуры с культурой европейской в самых разнообразных репрезентациях. Так, отдельные феномены европейской культуры, и прежде всего литературы, - направления, школы, творчество отдельных авторов - рассматриваются в этих очерках одновременно и в своей внутренней идентичности, и в аспекте их соотнесенности с русской традицией, и через призму самой их исторически сложившейся рецепции в России. С другой стороны, в энциклопедических очерках Вл. А. Лукова рассматривается рецепция европейской культуры «с русской стороны» - глазами отечественных ученых или, например, режиссеров, чье прочтение произведений западной литературы преломляется в их сцениче- 
ских интерпретациях. Так или иначе, но очерки Вл. А. Лукова стали посвоему уникальным феноменом диалога культур.

Полагаем, что энциклопедические очерки Вл. А. Лукова «Европейская культура в русском тезаурусе» могут найти практическое применение в научной практике, при подготовке к изданию собраний сочинений рассмотренных здесь европейских писателей, в курсах по лингвокультурологии для студентов-магистрантов. Кроме того, эти очерки представляют очевидный интерес для широкого круга читателей интересующихся европейским контекстом русской культуры.

Закончим тем, что книга Вл. А. Лукова, если вспомнить его расширенное определение тезауруса, дает «импульсы для радостной, интересной, многообразной жизни» с филологическим мировосприятием.

\section{СПИСОК ЛИТЕРАТУРЫ}

Луков, В. А., Луков, Вл. А. (2013) Тезаурусы II: Тезаурусный подход к пониманию человека и его мира : науч. монография. М. : Изд-во Нац. ин-та бизнеса. $640 \mathrm{c.}$

Луков, Вл. А. (2018а) Европейская культура в русском тезаурусе: Энциклопедические очерки : в 3 т. / под общ. ред. В. А. Лукова ; редкол.: В. А. Луков (сост., отв. ред.), Н. В. Захаров, В. Кофлер, Т. Ф. Кузнецова, В. П. Трыков. М. : Изд-во Моск. гуманит. ун-та. Т. 1. 560 с.

Луков, Вл. А. (2018b) Европейская культура в русском тезаурусе: Энциклопедические очерки : в 3 т. / под общ. ред. В. А. Лукова ; редкол.: В. А. Луков (сост., отв. ред.), Н. В. Захаров, В. Кофлер, Т. Ф. Кузнецова, В. П. Трыков. М. : Изд-во Моск. гуманит. ун-та. Т. 2. 640 с.

Луков, Вл. А. (2018c) Европейская культура в русском тезаурусе: Энциклопедические очерки : в 3 т. / под общ. ред. В. А. Лукова ; редкол.: В. А. Луков (сост., отв. ред.), Н. В. Захаров, В. Кофлер, Т. Ф. Кузнецова, В. П. Трыков. М. : Изд-во Моск. гуманит. ун-та. Т. 3.544 с.

Дата поступления: 19.03.2018 2.

Рабинович Валерий Самуилович - доктор филологических наук, профессор кафедры русской и зарубежной литературы Уральского гуманитарного института ФГАОУ ВО «Уральский федеральный университет имени первого Президента России Б. Н. Ельцина». Адрес: Россия, Екатеринбург, ул. Ленина, 51. Тел.: +7 (343) 389-94-12. Эл. адрес: philology-urfu@yandex.ru

Мухин Михаил Юрьевич - доктор филологических наук, директор департамента лингвистики, профессор кафедры фундаментальной и прикладной лингвистики и текстоведения Уральского гуманитарного института ФГАОУ ВО «Уральский федеральный университет имени первого Президен- 
та России Б. Н. Ельцина». Адрес: Россия, Екатеринбург, ул. Ленина, 51. Тел.: +7 (343) 389-95-62. Эл. адрес: mikhail.mukhin@urfu.ru

Rabinovich Valery Samuilovich, Doctor of Philology, Professor, Department of Russian and Foreign Literature, Ural Institute of Humanities, Ural Federal University named after the first President of Russia B. N. Yeltsin. Postal address: 51, Lenina St., Ekaterinburg, Russian Federation. Tel.: +7 (343) 389-94-12. E-mail: philology-urfu@yandex.ru

Mukhin Mikhail Yurievich, Doctor of Philology, Director, Department of Linguistics, Professor, Department of Fundamental and Applied Linguistics and Text Studies, Ural Institute of Humanities, Ural Federal University named after the first President of Russia B. N. Yeltsin. Postal address: 51, Lenina St., Ekaterinburg, Russian Federation. Tel.: +7 (343) 389-95-62. E-mail: mikhail.mukhin@urfu.ru

\section{Для циитирования:}

Рабинович В. С., Мухин М. Ю. Об энциклопедических очерках Вл. А. Лукова «Европейская культура в русском тезаурусе» [Электронный pecypc] // Горизонты гуманитарного знания. 2018. № 2. С. 86-89. URL: http://journals.mosgu.ru/ggz/article/view/764 (дата обращения: дд.мм.гггг). DOI: 10.17805/ggz.2018.2.8 